\author{
ANNA LEMAŃSKA \\ Uniwersytet Kardynała Stefana Wyszyńskiego w Warszawie \\ Instytut Filozofii
}

\title{
Postawa człowieka wobec przyrody a skuteczność ochrony środowiska
}

Man's Attitude Towards the Nature and Effectiveness of Environmental Protection

W XX wieku działania człowieka spowodowały głębokie zmiany środowiska. Obecnie nie ma na Ziemi praktycznie takich miejsc, które nie uległyby jakimś przeobrażeniom na skutek rozwoju cywilizacji. Dalsze pogłębianie tych procesów grozi jednak zniszczeniem biosfery, a w konsekwencji również ludzkości. Toteż podejmowane są rozmaite działania mające na celu powstrzymanie degradacji środowiska, czyli szeroko rozumianą ochronę przyrody. Skuteczność tych działań, a przede wszystkim ich moralna ocena, w istotny sposób są uzależnione od tego, jak rozumie się istotę człowieka, istotę rzeczywistości przyrodniczej i relację: człowiek - przyroda. Rozmaitych propozycji stanowisk dotyczących tych kwestii dostarczaja przede wszystkim dwie dyscypliny filozoficzne: antropologia filozoficzna i filozofia przyrody. Filozofia zatem stanowi swoisty fundament ekologii i sozologii ${ }^{1}$. W artykule, wykorzystując ustalenia z obszaru filozofii, podejmuję próbę określenia relacji: człowiek - przyroda, mogącą pomóc, jak sądzę, skuteczniej chronić środowisko.

\section{POSTAWA EGOIZMU CZY ODPOWIEDZIALNOŚCI ZA PRZYRODĘ}

Aby pokazać możliwe typy postaw ludzi wobec środowiska naturalnego, należy najpierw określić miejsce człowieka w przyrodzie. Niewątpliwie człowiek jest jednym $\mathrm{z}$ elementów przyrody. Jest bowiem zbudowany $\mathrm{z}$ takich pierwiast-

${ }^{1}$ Szerzej na ten temat: A. Lemańska, Filozofia przyrody jako podstawa dla sozologii, „Problemy Ekologii” 13(2009)6(78), s. 297-299. 
ków, jakie występują w przyrodzie, i z takich samych związków chemicznych, jak inne organizmy, podlega wszystkim prawom fizykochemicznym i uwarunkowaniom czasowo-przestrzennym. Co więcej, jest jednym z gatunków biologicznych, a tym samym współtworzy biosferę, wykazując wspólnotę z całą przyrodą ożywioną. To jest jednak tylko jeden $\mathrm{z}$ aspektów relacji człowiek - przyroda. Drugi jest związany z tym, że człowiek ma również zdolność do transcendowania przyrody, do swoistego wykraczania poza nią. Dzięki tej umiejętności człowiek w pewnym sensie może stanąć naprzeciw przyrody, może spojrzeć na siebie samego, na innych ludzi i na całą przyrodę z pozycji obserwatora, niejako „z zewnątrz”, a nie tylko i wyłącznie jako jeden z wewnętrznych elementów całości. Tym człowiek różni się, jak się wydaje, od wszystkich innych obiektów przyrodniczych, przynajmniej na Ziemi. Stanąć naprzeciw przyrody nie potrafi bowiem żaden przedmiot nieożywiony ani organizm żywy, nawet blisko spokrewniony z gatunkiem homo sapiens.

Nie będę rozpatrywać kwestii, czemu istota ludzka zawdzięcza tę zdolność wykraczania poza przyrodę. Istnieje całe spektrum poglądów na ten temat od uznających, że zdolność ta jest przejawem niematerialnej duszy czy ducha, aż po stwierdzenia, że po prostu wyewoluowała wraz ze skomplikowaniem się układu nerwowego i mózgu. Rozstrzygnięcie jednak tych kwestii nie ma dla dalszych moich rozważań szczególnego znaczenia, choć dotyka istotnego z punktu widzenia antropologii filozoficznej problemu - natury człowieka. W dalszej części przyjmuję zatem, że człowiek ma zdolność wykraczania poza przyrodę. Co do tego zgadza się przytłaczająca większość filozofów, przyrodników i teologów.

Ta szczególna umiejętność człowieka do transcendowania przyrody sprawia, że może on zajać dwie postawy w odmienny sposób określające jego relację do przyrody. Może mianowicie traktować ją egoistycznie jako przedmiot służący mu do zaspokajania potrzeb albo może przyjąć postawę odpowiedzialności za nią, wykraczającą w istotny sposób poza wąskie przedmiotowe jej traktowanie, czyli uznać przyrodę w pewnym sensie za podmiot ${ }^{2}$.

Relacja wyznaczana przez egoistyczne traktowanie przyrody jest charakterystyczna również dla innych gatunków biologicznych. Celem bowiem każdego organizmu jest przeżycie i rozmnożenie się - w tym przejawia się swojego rodzaju ekspansja życia. Środowisko jest z jednej strony „dostarczycielem” tego wszystkiego, co jest niezbędne do przeżycia zarówno osobniczego, jak i gatunku, z drugiej zaś stanowi źródło nieustannych zagrożeń, których należy unikać lub przed którymi należy się bronić. Organizmy zatem wykorzystują środowisko, czerpiąc z niego potrzebne elementy bądź zmieniają swe otoczenie, by stało się bardziej przyjazne dla danego gatunku. Powoduje to przekształcanie przez nie w rozmaity sposób ekosystemu, w którym żyją, co często prowadzi do degrada-

2 Traktuję przyrodę jako podmiot w sposób zbliżony do zaprezentowanego w publikacji E. Katz, Nature as Subject: Human Obligation and Natural Community, Lanham 1997, s. XVI. 
cji środowiska. W tym sensie można mówić o egoistycznym, przedmiotowym traktowaniu przyrody, gdyż w relacjach między danym organizmem a jego otoczeniem liczy się tylko doraźna korzyść danego organizmu czy w szerszej perspektywie - gatunku.

Ponieważ organizmy biologiczne nie są w stanie przewidywać długofalowych skutków swoich działań, to ich postępowanie jest nastawione na ich przeżycie w danym miejscu i danym czasie, czyli tu i teraz. Taka strategia może prowadzić do wręcz przeciwnego skutku, a mianowicie wymarcia danej populacji. Na przykład bakterie chorobotwórcze, rozmnażając się w sposób nieograniczony, doprowadzą do śmierci organizm, w którym żyją, i same również zginą, gdyż nie będą miały odpowiednich warunków do przetrwania. Drapieżniki polują i zabijają swe ofiary, by zaspokoić aktualnie odczuwany głód, i nie zastanawiają się nad tym, czy populacja ich potencjalnych ofiar jest dostatecznie liczna, by w nieco dalszej perspektywie czasowej było jeszcze na co polować.

Ludzie w gruncie rzeczy zachowują się podobnie jak pozostałe gatunki: poszerzają obszary swoich wpływów, by uzyskać jak najlepsze warunki do życia. Człowiek postępuje zatem tak samo jak inne organizmy, tyle że dzięki środkom technicznym na znacznie większą skalę. Przyroda jest wobec tego traktowana przez ludzi instrumentalnie jako źródło rozmaitych zasobów, które nie tylko umożliwiają im życie, ale je ułatwiają bądź uprzyjemniają. Zatem przy tym egoistycznym nastawieniu ma wartość dla człowieka, o ile dostarcza mu środków do przeżycia. Przy takim podejściu ochrona środowiska wynika z czysto pragmatycznych powodów. Człowiek, w przeciwieństwie do innych organizmów, może bowiem przewidzieć skutki swoich działań. Dostrzega zatem, że zasoby przyrody nie są nieograniczone, toteż ich dalsza eksploatacja, a także zanieczyszczenie środowiska zagrażają jego przeżyciu. Tym ludzie różnią się od bakterii. Uświadomienie sobie skutków bezwzględnego wykorzystywania przyrody zmusza do nakładania jakichś ograniczeń na eksploatację środowiska przez ludzi: np. wprowadza się limity na emisję siarki czy gazów cieplarnianych, buduje oczyszczalnie ścieków, dokonuje się recyklingu, projektuje i wytwarza energooszczędne urządzenia. Te rozmaite działania w pewnym zakresie chronią środowisko przed zbytnią degradacją. Należy podkreślić, że mają one na celu przede wszystkim przeżycie gatunku człowieka, gdyż dalsze niszczenie środowiska zagraża ludziom. Ochrona środowiska przy egoistycznym, przedmiotowym traktowaniu przyrody wynika zatem z ludzkiego lęku o przyszłość gatunku.

$\mathrm{Z}$ kolei podmiotowe (nieinstrumentalne) traktowanie przyrody przez człowieka jest uwarunkowane dostrzeżeniem, że poszczególne organizmy, całe ekosystemy czy nieożywione elementy środowiska naturalnego mają immanentne wartości tylko z tej racji, że istnieją. W ten sposób użyteczność dla ludzi przestaje być pierwszoplanowa. W konsekwencji uznaje się wartość życia innych organizmów czy trwanie rozmaitych elementów krajobrazowych niezależnie od 
korzyści dla człowieka. Może to prowadzić człowieka do poczucia wspólnoty z innymi organizmami żywymi i wzięcia ich niejako pod opiekę, a tym samym do chronienia ich przed zniszczeniem. Podjęcie odpowiedzialności za przyrodę sprawia, że istota ludzka, czerpiąc ze środowiska konieczne dobra naturalne, zarazem stara się nie naruszać tych immanentnych wartości innych bytów z obrębu przyrody. W tym przypadku ludzkie działania, które wywierają jakikolwiek wpływ na środowisko, są podejmowane łącznie z próbami zminimalizowania zmian następujących w przyrodzie. Dąży się zatem do tego, by korzystając z zasobów natury, jednocześnie zachować środowisko w stanie - jak najbardziej to możliwe - naturalnym. Ochrona środowiska polega nie tylko na unikaniu zanieczyszczania wody, powietrza i ziemi, lecz przede wszystkim na przeciwdziałaniu skutkom wynikającym z eksploatacji zasobów naturalnych, a także na powstrzymywaniu się od aktywności nawet korzystnych z jakiegoś punktu widzenia dla człowieka, ale mających destrukcyjny wpływ na środowisko. Obejmuje zatem znacznie szerszy zakres działań niż przy egoistycznym traktowaniu przyrody, jest też z ekonomicznego punktu widzenia kosztowniejsza i wymaga od ludzi jakichś wyrzeczeń.

Ochrona środowiska $\mathrm{w}$ tym przypadku wynika już nie tylko z egoistycznych pragnień człowieka. Jej celem jest bowiem ocalenie przyrody przed destrukcyjnym działaniem człowieka ze względu na jej wewnętrzne wartości. Na przykład nie zostanie wybudowany wielki hotel na Hali Gąsiennicowej, a przy okazji doprowadzona do niego wygodna, szerokopasmowa szosa, czy nie zostaną wytępione wszystkie słonie, gdyż Tatry i słonie mają wartość samą w sobie, a człowiek bierze odpowiedzialność za ich przetrwanie. Przy egoistycznej postawie dla takiej inwestycji nie ma przeciwwskazań, gdyż nawet tak głęboka ingerencja w środowisko, jak zbudowanie hotelu w środku Tatrzańskiego Parku Narodowego, nie zagraża bezpośrednio przeżyciu człowieka.

Postawa wobec przyrody w zasadniczy sposób przekłada się na zakres i sposób ochrony środowiska. Traktowanie przyrody jako przedmiotu nakłada na ludzkie działania tylko takie ograniczenia, które są niezbędne, by środowisko umożliwiało życie człowiekowi. Dla kogoś, kto traktuje przyrodę podmiotowo, taka postawa jest dalece niezadowalająca. W tym przypadku dąży się do minimalizowania wpływu człowieka na środowisko. Oczywiście, istota ludzka musi przekształcać środowisko, by nie zginąć, ale poszukuje się „złotego środka”: czerpie się to, co jest konieczne do przeżycia, starając się w drastyczny sposób nie zmieniać ekosystemów.

Należy podkreślić, że przyjęta postawa wobec przyrody jest świadomym wyborem każdego człowieka. Warto też dodać, że podmiotowo traktować przyrodę, wziąć za nią odpowiedzialność może tylko samoświadomy podmiot, który jest zdolny do przekroczenia swego indywidualnego czy grupowego egoizmu. Pierwszy typ postawy jest w pewnym sensie bardziej ,naturalny”, gdyż, jak to 
już stwierdziłam, jest charakterystyczny dla pozostałych gatunków biologicznych. Druga postawa wobec przyrody wymaga wyjścia poza wąsko pojęty interes człowieka i często kształtowana jest dopiero przez wychowanie.

\section{POSTAWY CZŁOWIEKA WOBEC PRZYRODY Z PUNKTU WIDZENIA FILOZOFII}

Uzasadnień dla obu postaw wobec przyrody poszukuje się m.in. w koncepcjach filozoficznych, które mogą dostarczać argumentów za egoistycznym, przedmiotowym lub odpowiedzialnym, podmiotowym traktowaniem przyrody. Nie ma tu jednak prostego przełożenia filozoficznej koncepcji człowieka i przyrody na wybór jednej z dwóch postaw wobec środowiska naturalnego. Obie postawy mogą być bowiem uzgodnione $\mathrm{z}$ różnymi stanowiskami filozoficznymi z zakresu antropologii i filozofii przyrody.

W literaturze dotyczącej kwestii ekologicznej toczy się spór między zwolennikami antropocentryzmu i zwolennikami stanowiska przeciwnego - biocentryzmu czy szerzej fizjocentryzmu. Antropocentryzm, jak sama nazwa wskazuje, stawia człowieka w centrum przyrody. Celem przyrody w tym ujęciu jest zaspokajanie jego potrzeb. Toteż ma ona wartość, o ile dostarcza człowiekowi środków do przeżycia. Z kolei fizjocentryzm uznaje, że przyroda ma swoje wewnętrzne, nieinstrumentalne wartości, że podmiotowa godność przysługuje nie tylko istocie ludzkiej, ale całej przyrodzie, zwłaszcza żywym organizmom, że istnieja naturalne cele w obszarze bytów przyrodniczych niezależne od istnienia człowieka ${ }^{3}$. Oba te stanowiska mogą występować w mniej lub bardziej skrajnej postaci. Stanowiska antropocentryzmu broni np. William Baxter ${ }^{4}$. Umiarkowany antropocentryzm przyjmuje np. Lothar Schäfer $^{5}$, niemiecki filozof. Krytykę tzw. głębokiej ekologii z pozycji humanizmu świeckiego przeprowadza francuski filozof, Luc Ferry ${ }^{6}$. Stanowiska biocentryzmu bronią m.in. Paul Warren Taylor ${ }^{7}$, Klaus Michael Meyer-Abich ${ }^{8}$, Hans Jonas ${ }^{9}$, Reinhard Löw ${ }^{10}$, w Polsce

\footnotetext{
${ }^{3}$ Zob. Z. Wróblewski, Natura i cele: dyskusja argumentu teleologicznego na rzecz ochrony przyrody, Lublin 2010, s. 190-192.

${ }^{4}$ Zob. W. Baxter, People or penguins: the case for optimal pollution, New York 1974.

${ }^{5}$ Zob. L. Schäfer, Samookreślenie człowieka i jego stosunek do przyrody, „Acta Universitatis Lodziensis. Folia Philosophica" (1993)10, s. 116-135.

${ }^{6}$ Zob. L. Ferry, Le nouvel ordre ecologique: l'arbre, l'animal et l'homme, Paris 1992.

${ }^{7}$ Zob. P.W. Taylor, Respect for Nature. A Theory of Environmental Ethics, New York 1986.

${ }^{8}$ Zob. K.M. Meyer-Abich, Wege zum Frieden mit der Natur. Praktische Naturphilosophie für die Umweltpolitik, München 1997. 1996.

${ }^{9}$ Zob. H. Jonas, Zasada odpowiedzialności. Etyka dla cywilizacji technologicznej, Kraków

${ }^{10}$ Zob. R. Löw, Natürliche Ziele. Geschichte und Wiederentdeckung teleologischen Denkens, Stuttgart 2005.
} 
- Zdzisława Piątek ${ }^{11}$. Bardzo radykalne stanowisko biocentryzmu reprezentuje Albert Schweitzer ${ }^{12}$.

Skrajny antropocentryzm daje człowiekowi prawo dowolnego zmieniania i kształtowania środowiska - granica jest tylko niedoprowadzenie do zagłady biosfery, gdyż wtedy zginie również gatunek człowieka. Z kolei skrajny biocentryzm, uznając jednakową wartość każdego życia, może prowadzić do absurdów, nie uwzględniając prawa człowieka do życia.

Antropocentryzm i fizjocentryzm są stanowiskami filozoficznymi, których zadaniem jest ujawnienie istoty przyrody i miejsca w niej człowieka. Propozycje te określają relację człowiek - przyroda, próbując dotrzeć do tego, jaka jest obiektywna, prawdziwa natura przyrody. Natomiast to, co nazywam egoistyczna postawą wobec przyrody i postawą odpowiedzialności za nią, jest świadomym wyborem człowieka jego własnego, subiektywnego nastawienia wobec przyrody. Oczywiście, nietrudno dostrzec, że stanowiska filozoficzne antropocentryzmu i fizjocentryzmu mogą wzmacniać lub osłabiać te postawy. I tak antropocentryzm może dostarczać argumentów za przedmiotowym, egoistycznym traktowaniem przyrody. Z kolei fizjocentryzm może prowadzić do zajęcia postawy odpowiedzialności i do podmiotowego traktowania przyrody. Związki antropocentryzmu z przedmiotowym traktowaniem przyrody, a fizjocentryzmu z jej podmiotowym traktowaniem nie stanowią jednak jakiejś konieczności. Co więcej, umiarkowane wersje obu stanowisk zbliżają się do siebie: fizjocentryzm nie musi oznaczać pozbawiania człowieka prawa do życia, a tym samym do ingerowania w przyrodę i jej przekształcania, zaś antropocentryzm może łączyć się z uznaniem, że przyroda jest darem dla nas, darem nam użyczonym, nie jest zatem naszą własnością, z którą możemy robić, co chcemy ${ }^{13}$. Antropocentrysta zatem może również przyrodę traktować odpowiedzialnie.

\section{POSTAWY CZŁOWIEKA WOBEC PRZYRODY Z PUNKTU WIDZENIA TEOLOGII}

Warto jeszcze na problem ochrony środowiska spojrzeć z perspektywy teologii, bowiem na widzenie świata przyrody i miejsca w niej człowieka przez ostatnie dwa tysiące lat istotny wpływ wywierało chrześcijaństwo. Tym samym również będzie mieć ono znaczenie przy próbach określenia z perspektywy filo-

${ }^{11}$ Zob. Z. Piątek, Etyka środowiskowa. Nowe spojrzenie na miejsce czlowieka w przyrodzie, Kraków 1998; Z. Piątek, Ekofilozofia, Kraków 2008, s. 137-149.

${ }^{12}$ Znane jest stwierdzenie Alberta Schweitzera: „Jestem życiem, które pragnie żyć, pośród życia, które pragnie żyć” - A. Schweitzer, Gesammelte Werke, t. 1, München 1974, s. 377.

${ }^{13}$ „Różne stworzenia, chciane w ich własnym bycie, odzwierciedlają, każde na swój sposób, jakiś promień nieskończonej mądrości i dobroci Boga. Z tego powodu człowiek powinien szanować dobroć każdego stworzenia, by unikać nieuporządkowanego wykorzystywania rzeczy, które lekceważy Stwórcę oraz powoduje zgubne konsekwencje dla ludzi i ich środowiska" - Katechizm Kościoła katolickiego 339, Poznań 1994, s. 88. 
zoficznej relacji człowieka do przyrody. Co więcej, chrześcijaństwo ze swoją koncepcją człowieka jest oskarżane o doprowadzenie do kryzysu ekologicznego. Źródeł kryzysu dopatruje się w relacji człowieka do przyrody wynikającej z Biblii. Taką tezę postawił Lynn Townsend White, wskazując, że ,judeochrześcijańskie podejście do środowiska usprawiedliwia [...] charakterystyczną dla cywilizacji Zachodu «eksploatacyjną» relację do przyrody"14. Stwierdzenie White'a wywołało ożywioną dyskusję, w której podawane są argumenty zarówno za tym radykalnym stanowiskiem, jak i przeciw niemu. W szczególności przeciwnicy tezy White'a wskazują na pozytywną rolę chrześcijaństwa w przezwyciężaniu kryzysu ekologicznego. Warte podkreślenia jest to, że zarówno zwolennicy, jak i przeciwnicy stanowiska White'a odwołują się do Biblii. Wydaje się zatem, że poglądy w tej kwestii zależą w istotny sposób od interpretacji Pisma Świętego oraz budowanego na tej podstawie obrazu człowieka.

Ważnym głosem $\mathrm{w}$ dyskusji dotyczącej ochrony środowiska i roli w tym chrześcijaństwa jest ostatnia encyklika papieża Franciszka Laudato si'. Papież identyfikuje przyczyny kryzysu ekologicznego i wskazuje środki zaradcze. Pokazuje również, że chrześcijaństwo jest sprzymierzeńcem w wysiłkach mających na celu zahamowanie degradacji środowiska ${ }^{15}$.

Ponieważ nie jestem teologiem, to nie do mnie należy ocena, która z postaw wobec przyrody (jej przedmiotowe czy podmiotowe traktowanie) jest bliższa chrześcijaństwu. Jak się wydaje, obie postawy, zwłaszcza w swych umiarkowanych konsekwencjach, znajdują uzasadnienie w Piśmie Świętym. Z jednej strony bowiem człowiek został stworzony na obraz i podobieństwo Boga i ma czynić

${ }^{14}$ R.F. Sadowski, Filozoficzny spór o rolę chrześcijaństwa w kwestii ekologicznej, Warszawa 2015, s. 102.

${ }^{15}$ Warto przytoczyć 67. paragraf encykliki Laudato si': „Nie jesteśmy Bogiem. Ziemia istniała wcześniej niż my i została nam dana. Pozwala to odpowiedzieć na oskarżenie stawiane myśli judeo-chrześcijańskiej: mówi się, że ponieważ opis Księgi Rodzaju zachęca nas do «panowania» nad ziemią $(R d z 1,28)$, więc sprzyja bezlitosnej eksploatacji natury, przedstawiając dominujący i destrukcyjny obraz człowieka. Nie jest to poprawna interpretacja Biblii, tak jak rozumie ją Kościół. Choć to prawda, że czasami chrześcijanie błędnie interpretowali Pismo Święte, to musimy dziś stanowczo stwierdzić, iż z faktu bycia stworzonymi na Boży obraz i nakazu czynienia sobie ziemi poddaną nie można wywnioskować absolutnego panowania nad innymi stworzeniami. Ważne jest odczytywanie tekstów biblijnych w ich kontekście, we właściwej hermeneutyce, i przypominanie, że zachęcają nas one do «uprawiania i doglądania» ogrodu świata (por. $R d z 2,15$ ). Podczas gdy «uprawianie» oznacza oranie i kultywowanie, to «doglądanie» oznacza chronienie, strzeżenie, zachowanie, bronienie, czuwanie. Pociaga to za sobą relację odpowiedzialnej wzajemności między człowiekiem a naturą. Każda wspólnota może wziąć z dóbr ziemi to, czego potrzebuje dla przeżycia, ale ma również obowiązek chronienia jej i zapewnienia, by nadal była ona płodna dla przyszłych pokoleń. Bo ostatecznie «do Pana należy ziemia» (por. Ps 24,1), do Niego należy «ziemia i wszystko, co jest na niej» (Pwt 10,14). Z tego względu Bóg odrzuca wszelkie roszczenia do własności absolutnej: «Nie wolno sprzedawać ziemi na zawsze, bo ziemia należy do Mnie, a wy jesteście u Mnie przybyszami i osadnikami» (Kpt 25,23)" - Franciszek, Encyklika Laudato si', Kraków 2015. 
sobie ziemię poddaną $(\operatorname{Rdz} 1,28)$. Może to prowadzić do antropocentryzmu i przedmiotowego traktowania przyrody ${ }^{16}$. $\mathrm{Z}$ drugiej strony Bóg kocha wszystko, co stworzył (Mdr 11,20-26), a więc całą przyrodę, a nie tylko wyłącznie ludzi. Nakłada to na każdego człowieka obowiązek szacunku dla przyrody jako dzieła Bożego.

Warto dodać, że w świetle religii chrześcijańskiej człowiek ma określone obowiązki wobec przyrody i nie może nią dowolnie dysponować. Pokusę maksymalnego wykorzystywania zasobów przyrody dla ludzkich egoistycznych celów stwarzają natomiast, wbrew pozorom, stanowiska materialistyczne czy naturalistyczne. Brakuje $\mathrm{w}$ nich bowiem zewnętrznego w stosunku do przyrody czynnika, do którego można odnosić ocenę działań człowieka. Jedynym ograniczeniem staje się tu tylko dalsze istnienie ludzkości. Perspektywa przypadkowego powstania Ziemi, życia na niej i gatunku Homo sapiens może prowadzić do uznania, że przyroda nie ma w sobie żadnej wartości, a wtedy odpowiedzialność człowieka sprowadza się wyłącznie do odpowiedzialności za przetrwanie własnego gatunku.

Warto zwrócić uwage, że w świetle nauk przyrodniczych skrajny antropocentryzm nie znajduje uzasadnienia. Ogrom Wszechświata zarówno przestrzenny, jak i czasowy, odkrycie, że Ziemia jest w gruncie rzeczy nic nieznaczącym pyłkiem w Kosmosie, a z praw przyrody wynika, że ludzkość na Ziemi ma tylko bardzo ograniczony czas trwania, gdyż Ziemia jako obiekt astronomiczny nie jest wieczna, skłaniają do uznania, że człowiek nie jest jakimś szczególnym, wyróżnionym rodzajem bytu we Wszechświecie.

Jak się wydaje, ani stanowisko filozoficzne fizjocentryzmu, któremu często brakuje zewnętrznie ufundowanej hierarchii wartości poszczególnych bytów $\mathrm{z}$ obrębu przyrody, ani stanowisko egoistycznego antropocentryzmu nie stanowią właściwej perspektywy dla działań mających na celu ochronę środowiska. Wydaje się, że taką perspektywę może stwarzać „teocentryzm”, który uznaje Boga za Stwórcę Wszechświata. W tej perspektywie przyrodę trzeba traktować jak dobro, za które człowiek musi wziąć odpowiedzialność. Człowiek odpowiada za środowisko, w którym żyje, nie tylko przed przyszłymi pokoleniami czy ludzkością, ale przede wszystkim przed Stwórcą świata, a więc rzeczywistym dysponentem całej przyrody.

Bez względu na swoją postawę wobec przyrody: egoistyczną czy odpowiedzialności, ludzie zdają sobie sprawę z konieczności ochrony przyrody. Działa-

\footnotetext{
${ }^{16} \mathrm{~W}$ taki sposób interpretuje ten fragment Księgi Rodzaju Zdzisława Piątek: jeśli przyjmiemy, „,̇e Bóg stworzył je [istoty żywe] dla dobra istot obdarzonych rozumem, to możemy je bez ograniczeń wykorzystywać czysto instrumentalnie do realizacji naszych «wyższych» celów" - Z. Piątek, Etyka środowiskowa, dz. cyt., s. 24.
} 
nia podejmowane w tym zakresie motywowane egoistycznymi celami człowieka doraźnie mogą być skuteczne. Wydaje się jednak, że na dłuższą metę podmiotowe potraktowanie przyrody pozwala na efektywniejszą jej ochronę. Jest to uwarunkowane tym, że nie potrafimy w pełni przewidzieć wszystkich skutków naszych działań. Przyroda, biosfera jest systemem wrażliwym na wszelkie zaburzenia. Relacje między różnymi organizmami zasiedlającymi tę samą niszę ekologiczną oraz wpływ rozmaitych czynników abiotycznych na te organizmy są bowiem tak skomplikowane i różnorodne, że samo ich poznanie nie wystarcza, by podejmować skuteczne działania zapobiegające degradacji środowiska naturalnego. Toteż takie postępowanie wobec przyrody, które prowadzi do zachowania środowiska w jego pierwotnej postaci, może okazać się korzystniejsze również dla ludzi niż drastyczne jego przekształcanie nawet przynoszące doraźne zyski.

\section{BIBLIOGRAFIA}

Baxter W., People or penguins: the case for optimal pollution, New York 1974.

Ferry L., Le nouvel ordre ecologique: l'arbre, l'animal et l'homme, Paris 1992.

Franciszek, Encyklika Laudato si' (24.05.2015), Kraków 2015.

Jonas H., Zasada odpowiedzialności. Etyka dla cywilizacji technologicznej, Kraków 1996.

Katechizm Kościoła katolickiego, Poznan 1994.

Katz E., Nature as subject: Human obligation and natural community, Lanham 1997.

Lemańska A., Filozofia przyrody jako podstawa dla sozologii, „Problemy Ekologii” 13(2009)6(78), s. 297-299.

Löw R., Natürliche Ziele. Geschichte und Wiederentdeckung teleologischen Denkens, Stuttgart 2005.

Meyer-Abich K.M., Wege zum Frieden mit der Natur. Praktische Naturphilosophie für die Umweltpolitik, München 1997.

Piątek Z., Ekofilozofia, Kraków 2008.

Piątek Z., Etyka środowiskowa. Nowe spojrzenie na miejsce czlowieka w przyrodzie, Kraków 1998.

Sadowski R.F., Filozoficzny spór o rolę chrześcijaństwa w kwestii ekologicznej, Warszawa 2015.

Schäfer L., Samookreślenie czlowieka i jego stosunek do przyrody, „Acta Universitatis Lodziensis. Folia Philosophica" (1993)10, s. 116-135.

Schweitzer A., Gesammelte Werke, t. 1, München 1974.

Wróblewski Z., Natura i cele: dyskusja argumentu teleologicznego na rzecz ochrony przyrody, Lublin 2010. 


\section{SUMMARY}

The article presents two human attitudes towards nature: a selfish attitude and the attitude of responsibility. Selfish attitude treats nature as an object to satisfy human needs. In this case the environmental protection is caused by fear of the destruction of biosphere and, consequently, mankind. The attitude of responsibility is characterized by a subjective treatment of nature. In this case, the environment is protected because the nature has its internal values.

\section{Keywords}

the relationship man-nature, environmental protection, anthropocentrism, biocentrism, responsibility for nature

Anna Lemańska, prof. dr hab., kierownik Katedry Filozofii Przyrody Wydziału Filozofii Chrześcijańskiej UKSW, od 2001 r. na stanowisku profesora nadzwyczajnego. Studia na Wydziale Matematyki i Mechaniki Uniwersytetu Warszawskiego oraz na kierunku filozofii przyrody na Wydziale Filozofii Chrześcijańskiej Akademii Teologii Katolickiej w Warszawie. Autorka książki: Filozofia przyrody a nauki przyrodnicze. Wybrane zagadnienia z teorii filozofii przyro$d y$, Warszawa 1998, oraz kilkudziesięciu artykułów z zakresu filozofii. 